ACTA THERIOLOGICA

VOL. 22, 21: 296-307, 1977

\title{
Live Trap Preference Among Grassland Mammals ${ }^{1}$
}

\author{
Robert K. ROSE ${ }^{2}$, Norman A. SLADE \& James H. HONACKI
}

Rose R. K., Slade N. A. \& Honacki J. H., 1977: Live trap preference among grassland mammals. Acta theriol., 22, 21: 296-307 [With 3 Tables]

In two independent studies, small mammals of grassland communities in eastern Kansas, when given a choice, preferred Fitch to Sherman live traps. Except for the harvest mice in the demographic study, the type of preferred trap and magnitude of selection was remarkably comparable, with microtines showing slight, and cricetines strong, preferences overall. The merits of each type of trap are compared, and related to season, weather, prior experience, and trap-associated mortality.

[Dept. Syst. Ecol. and Mus. Nat. Hist., Univ. Kansas, Lawrence, Kansas 66045, USA].

\section{INTRODUCTION}

Small mammals are trapped for purposes of (1) survey, (2) sampling, as in genetic or cytological study, and (3) recording demographic changes in a population. Wi ener \& S mith (1972) have shown that breakback traps are probably the best choice for survey purposes, because they catch a variety of sizes and some species not easily live-trapped, e.g., shrews. Live traps are required for sampling, even though animals may be released after collection of serum or cells.

For demographic studies, it is imperative that individuals of all size, sex, and reproductive classes are captured in each trapping session, and that individuals are maintained in good condition until examined and released. An additional requirement of live traps is a low failure rate, failure being the inability to entrap or retain mice that enter. Cost, both of purchase and maintenance, and of time required to set and run, may also be important.

In this paper we examine the relative merits of two kinds of live traps, Sherman's $7.6 \times 7.6 \times 25.4 \mathrm{~cm}$ aluminum trap and $\mathrm{R}$ o s e's modification (1973) of the live trap of F i t c h (1950). The latter trap has a mesh

${ }^{1}$ Please address reprint requests to: Publications Secretary, Museum of Natural History, Lawrence, Kansas 66045, USA.

2 Present address of Rose: Dept. Biol. Georgetown Univ., Washington, D.C. 20057. 
hardware cloth trap $(7 \times 7 \times 30 \mathrm{~cm})$ attached to a nest box made from a \# 10 (@3 L) tin can. From 1971 to 1975 , in two independent studies, we live-trapped native small mammals in eastern Kansas on a regular, usually biweekly, basis using both types of trap at each trapping station. The study of Rose, described first below, required 15 to 20 prairie voles (Microtus ochrogaster) every two weeks (sampling) for genetic analysis, as well as for reproductive and wounding estimates for the population. Slade's study (demography) was of a population of the hispid cotton rat (Sigmodon hispidus). Coincidentally, we obtained some information about the kinds (survey) of small mammals living in oldfield communities in eastern Kansas.

\section{MATERIALS AND METHODS}

From May, 1971, through May, 1974, samples of prairie voles were removed from five collecting sites on or near the Nelson Environmental Studies Area (NESA) of the University of Kansas, 14 kilometers northeast of Lawrence, in eastern Kansas. This locality is situated at the eastern margin of the Great Plains, near the geographical center of the United States at $39^{\circ} \mathrm{N}, 95^{\circ} \mathrm{W}$, at an elevation of about $300 \mathrm{M}$. At each collecting site a line of 45 stations, each with one Sherman and one Fitch trap, was established through prime vole habitat. A trapping session was terminated when a sample of 15 to 20 voles had been obtained, or after four days of trapping. At moderate-to-high densities of voles, a single day of trapping often sufficed. The Sherman traps were then picked up, locked open by placing a wooden tongue depressor under the treadle, and moved to the next collecting site in sequence, and prebaited, upside down, for 10-13 days. (Clean Sherman traps were placed into rotation as needed). The 45 Fitch traps, positioned permanently in place at each collecting site, were also prebaited for $10-13$ days and were locked open for the eight weeks following active trapping. Occasionally during this interval, especially in the winter months, the prairie hay in the nest box of a Fitch trap was used as a communal nest for as many as 12 harvest mice or prairie deermice, indicating that the traps were entered even after the bait [commercial chicken scratch feed, a mixture of cracked corn (Zea mays), wheat (Triticum aestivum) and milo (Sorghum vulgare)] had been consumed. During trapping prairie voles of 20 gram $(\mathrm{g})$ weight or greater were permanently removed to the laboratory; other small mammals were released, except for $S$. hispidus during some periods, especially in autumn, 1972, when they, too, were removed to the laboratory for another study. In all, nine species of small mammal were caught for a total of 1542 observations; almost all are one observation per animal, and they will be treated as such in the analysis. In order of decreasing frequency of capture, the species captured were $M$. ochrogaster, Peromyscus maniculatus bairdii (prairie deermouse), $S$. hispidus, Synaptomys cooperi (southern bog lemming), $P$. leucopus (white-footed mouse), Reithrodontomys megalotis and $R$. montanus (harvest mice), Mus musculus (house mouse), Blarina brevicauda (short-tailed shrew), and Zapus hudsonius (meadow jumping mouse).

From September, 1973, through June, 1975, a 1.8 hectare grid $(10 \times 10,15 \mathrm{M}$ intervals) in old field, also at NESA, was trapped biweekly, except monthly from December through February, by Slade and Honacki. This grid, also with one trap 
of each type at each station, provided information on the tendency of tagged individuals to prefer one or the other type of trap. The list of species captured is comparable in both studies; however, the frequency of occurrence differed somewhat. On the demographic grid, captures were most numerous for harvest mice, followed by prairie voles, cotton rats, prairie deermice, house mice, southern bog lemmings and others. In all, 2502 observations were made on the grid of cases in which a small mammal had a choice of type of trap to enter.

In this paper, then, we report on the preference shown by small mammals for Fitch and Sherman traps from two studies: Rose's removal trapping and Slade's mark-and-release study. (Hereafter, "removal " refers to Rose's study and "demography « to Slade and Honacki's Sigmodon grid.) Frequently both types of trap at a given station contained a small mammal. Such stations are not included in the analysis of trap preference because there is no way to determine which mammal caught at the station had a choice of trap types, and which did not. The term "preference is meant to imply that a small mammal did make a choice to enter one trap rather than the other. In our design, we have attempted to overcome any advantage Fitch traps may gain by virtue of being permanently positioned by placing the Sherman traps in runways at the time of prebaiting.

Tests of significance are made using Chi-square and $G$ analysis.

\section{RESULTS}

Overall, more captures occurred in Fitch than in Sherman traps (removal, 882:660, $\chi^{2}=31.96,1$ df, $p<.001$; demography, 1634:868, $\left.\chi^{2}=234.51,1 \mathrm{df}, p<.001\right)$. Of greater interest is the preference of individuals of the six common species (Table 1). Except for the harvest mice (Reithrodontomys) which showed a strong preference for Fitch traps only in the demographic study, the type of preferred trap and magnitude of selection in remarkably comparable. The microtines, M. ochrogaster and $S$. cooperi, showed a slight preference for Fitch traps and the more scansorial cricetines (S. hispidus, P. maniculatus and P. leucopus) a uniformly strong preference for Fitch traps. Thus, the pattern within a species seems to be similar whether one capture per individual (as in removal trapping) or including several observations of the same individual (as in the demographic study).

\section{Effects of Season}

We examined for effects of season on trap preference by dividing the year into four seasons, with the months of December through February constituting winter, June - August the summer, and the intervening months spring and autumn. Although none of the six small mammals hibernates, only four species had sufficient year round observations to permit a meaningful analysis of seasonal effects. The relationship between trap preference and season for the four species is summarized in Table 2. In the demographic study, $M$. ochrogaster preferred Fitch traps 
in the winter but showed a (non-significant) shift to Sherman traps in the summer and autumn. Roughly the same trend appeared in the analysis of prairie voles from removal sites, except that the summer shift away from Fitch traps did not extend into autumn. Synaptomys shows

Table 1

Number of captures by trap type for six most common species. $R$ designates removal study (one observation per individual) and $D$ demographic study (including several observations for some individuals). One, two and three asterisks $\left(^{*}\right)$ represent the $.05, .01$, and .001 levels of significance: n.s. is not significant $\alpha$.

\begin{tabular}{lcccc}
\hline & Fitch & Sherman & $\begin{array}{c}\text { Level of } \\
\text { significance }\end{array}$ \\
\hline M. ochrogaster & $R$ & 313 & 248 & $*$ \\
P. leucopus & $D$ & 514 & 494 & n.s. \\
& $R$ & 42 & 20 & $* *$ \\
P. maniculatus & $D$ & 8 & 5 & n.s. \\
& $R$ & 206 & 157 & $* *$ \\
Reithrodontomys & $D$ & 150 & 53 & $* * *$ \\
S. hispidus & $R$ & 60 & 44 & n.s. \\
& $D$ & 645 & 74 & $* * *$ \\
S. cooperi & $R$ & 152 & 86 & $* *$ \\
& $D$ & 295 & 205 & $* *$ \\
& $R$ & 104 & 90 & n.s. \\
& $D$ & 8 & 4 & n.s.
\end{tabular}

Table 2

Effect of season on number of captures by trap type, for four common species. Refer to Table 1 for meaning of $R, D$, and * (no asterisk =n.s.). In each pair of numbers the first (e.g., 89) represents the number caught in Fitch traps, the second (63) in Sherman traps. Warmer season is comprised of spring through autumn.

\begin{tabular}{|c|c|c|c|c|c|}
\hline & & M. ochrogaster & P. maniculatus & Reithrodontomys & S. hispidus \\
\hline Winter & $\begin{array}{l}R \\
D\end{array}$ & $\begin{array}{c}89 / 63^{*} \\
131 / 87^{* *}\end{array}$ & $\begin{array}{l}93 / 68^{*} \\
54 / 15^{* * *}\end{array}$ & $\begin{array}{c}19 / 15 \\
315 / 33^{* * *}\end{array}$ & $\begin{array}{c}33 / 20 \\
111 / 41^{* * * *}\end{array}$ \\
\hline Spring & $\begin{array}{l}R \\
D\end{array}$ & $\begin{array}{l}103 / 88 \\
186 / 152\end{array}$ & $\begin{array}{l}41 / 31 \\
58 / 24^{* *}\end{array}$ & $\begin{array}{l}26 / 19 \\
178 / 21^{* * *}\end{array}$ & $\begin{array}{l}16 / 16 \\
22 / 25\end{array}$ \\
\hline Summer & $\begin{array}{l}R \\
D\end{array}$ & $\begin{array}{l}39 / 46 \\
88 / 121\end{array}$ & $\begin{array}{l}22 / 26 \\
25 / 4^{* *}\end{array}$ & $\begin{array}{c}9 / 3 \\
49 / 4^{* *}\end{array}$ & $\begin{array}{l}68 / 34^{* * *} \\
11 / 24^{* *}\end{array}$ \\
\hline Autumn & $\begin{array}{l}R \\
D\end{array}$ & $\begin{array}{c}82 / 51^{* *} \\
109 / 134\end{array}$ & $\begin{array}{l}50 / 32 \\
13 / 10\end{array}$ & $\begin{array}{c}6 / 7 \\
103 / 16^{* * *}\end{array}$ & $\begin{array}{r}35 / 16^{* *} \\
151 / 114^{*}\end{array}$ \\
\hline $\begin{array}{l}\text { Warmer } \\
\text { season totals }\end{array}$ & $\begin{array}{l}R \\
D\end{array}$ & $\begin{array}{l}224 / 185 \\
381 / 407\end{array}$ & $\begin{array}{l}113 / 89 \\
96 / 38^{* *}\end{array}$ & $\begin{array}{l}41 / 29 \\
330 / 41^{* * *}\end{array}$ & $\begin{array}{l}119 / 66^{* *} \\
194 / 163\end{array}$ \\
\hline
\end{tabular}

trends similar to the prairie vole. The picture is not so clear for hispid cotton rats, however. Although both studies show a strong preference by cotton rats for Fitch traps overall, the seasonal preference differs. Specifically, on the demographic grid the overall preference is due 
mostly to very strong selection of Fitch traps in the winter, and to a lesser extent in autumn; although no preference is evident, there is a trend toward Sherman traps during spring and summer. For the removal trapping, there is no clear preference in the winter or spring, but Fitch traps are preferred in summer and autumn. Combining the two studies, it appears that cotton rats prefer Fitch in the autumn, and in the winter when the trapping interval is fairly brief.

For P. maniculatus, both studies indicate a preference for Fitch traps in the winter and continued preference throughout the year on the demographic grid but not on the removal sites. The warm season trend toward a preference for Sherman traps on the removal sites is not at all seen in the demographic study, where a strong preference for Fitch traps prevails at all seasons except autumn.

Among harvest mice, the pattern of trap preference is most consistent across seasons within each study, but is most different between studies. On the demographic grid the choice is overwhelmingly and systematically Fitch traps; on the removal sites trap selection by harvest mice appears to be by random choice in all seasons.

\section{Effects of Weather}

For the removal study it was possible to examine for effects of weather. For each trapping day, one of four designations was assigned to describe the weather: clear, rainy, snowy or cloudy. These designations are not rigid, of course, and do not account, for example, for mice handled on a sunny morning, some of which may have entered traps in early evening of the previous cloudy day. Among prairie voles only on clear days was there a significant preference for Fitch traps $\left(\chi^{2}=12.46\right.$, $1 \mathrm{df}, p<.005$ ).

Hispid cotton rats show obvious preferences on clear $\left(\chi^{2}=11.16,1 \mathrm{df}\right.$, $p<.005)$ and rainy $\left(\chi^{2}=7.40,1 \mathrm{df}, .01>p>.005\right)$ days. None of the 238 observations of Sigmodon occurred in association with new snow. With the center of distribution of Sigmodon in Mexico, S. hispidus is likely to be poorly suited to severe winters. Although its northward movement in this century through Kansas and into Nebraska is well documented (Cockrum, 1948; Genoways \& Schlitter, 1966), relatively little is known of the winter ecology of hispid cotton rats in the Central Plains (see discussion). However, in eastern Kansas snows are infrequent, usually light, and melt quickly. It is possible that cotton rats temporarily depress their activity patterns when the ground is covered with snow (Goertz, 1964) or seek underground or other refuges (B a r, Fleharty \& Altman, 1975). 
Neither Peromyscus species demonstrated a significant preference in different weather conditions, although all nine captures of $P$. leucopus on snowy days were in Fitch traps. Harvest mice preferred Fitch traps $\left(\chi^{2}=6.64,1 \mathrm{df}, p=.01\right)$ on clear days, and appeared to select traps at random in other weather. Overall, there are few surprises in the analysis of weather effects, except perhaps the high degree to which Fitch traps are preferred on sunny days $\left(\chi^{2}=25.13,1 \mathrm{df}, p<.001\right)$.

\section{Effects of Prior Experience}

In mark-and-release studies, the probability of entering a trap may be altered by an animal's prior experience. B alph (1968 and pers. comm.) has proposed that being trapped is a form of operant conditioning in which an animal receives both reward, in the form of food, shelter, and nesting material, and punishment, the stress of being confined, handled, and tagged. The rate at which an individual is recaptured in the same type of trap should reflect the balance of rewards and punishment associated with the trap. The null hypothesis, that both types are equally rewarding and stressful, is suggested because food, length of confinement and handling time are comparable. In the demographic study, only cotton rats were tagged and could be tested for prior experience.

To avoid bias due to initial trap selection, we have considered separately the tendency to be recaptured for animals previously captured in Fitch and Sherman traps. Table 3 shows the distribution of 601 cotton

Table 3

Distribution of recaptures of $S$. hispidus according to previous capture history. Including stations with both traps occupied.

\begin{tabular}{lccc}
\hline & $\begin{array}{c}\text { First or } \\
\text { prior capture }\end{array}$ & $\begin{array}{c}\text { Subsequent capture } \\
\text { in Fitch trap }\end{array}$ & $\begin{array}{c}\text { Subsequent capture } \\
\text { in Sherman trap }\end{array}$ \\
\hline Fitch trap & 312 & 186 & 126 \\
Sherman trap & 289 & 139 & 150 \\
\hline
\end{tabular}

rats trapped two or more times. A contingency Chi-square $(8.015,1 \mathrm{df}$, $p<.005$ ) was used to examine the probability of successive capture by trap type. Specifically, given the slight though non-significant $\left(\chi^{2}=\right.$ $=0.880,1 \mathrm{df}$ ) tendency for cotton rats to prefer Fitch traps at first or prior capture, there was a significant tendency for animals to be recaptured in the same type of trap.

The affinity for trap type appeared to be slightly stronger for rats captured in Fitch traps in that 60 percent were captured in Fitch traps 
on the subsequent capture, but only 52 percent of rats from Sherman traps were immediately recaptured in the same type of trap. Viewing the data in this manner, as a 2-state Markovian process, allowed us to predict steady-state capture frequencies if the conditional probabilities of trap type remain unchanged. The steady-state probabilities are 0.56 and 0.44 for capture in Fitch and Sherman traps respectively. These values compare very well with the capture frequencies of cotton rats in the entire demographic study.

\section{Mortality Associated with Type of Trap}

For the demographic study it was possible to measure trap-related mortality for four species. Consistently lower mortality was observed in Fitch traps for all species (Microtus, $\chi^{2}=22.95,1 \mathrm{df}, p<.001 ; P$. maniculatus, $\chi^{2}=9.65,1 \mathrm{df}, p<.01$; Reithrodontomys, $\chi^{2}=21.05 ; 1 \mathrm{df}$, $p<.001$ ), although the difference for Sigmodon was not significant $\left(\chi^{2}=1.75,1 \mathrm{df}\right.$, n.s.). Only Microtus had sufficient observations to examine for seasonal effects; mortality was significantly lower in Fitch traps in all seasons except winter.

\section{DISCUSSION}

In this paper we have presented evidence that small mammals in oldfield communities in eastern Kansas, if given a choice of two types of live trap, prefer Fitch to Sherman traps overall. Differences in the degree of preference undoubtedly relate to several factors (reward and punishment) but the relationship between energy dynamics and sustained productivity of the vegetation in these communities is likely to be very important. The demographic grid was established to study a population of $S$. hispidus, a recent migrant into eastern Kansas where it often reaches high densities in early seral stages characterized by sunflowers (Helianthus sp.) and annual grasses such as foxtail (Setaria). One half of the demographic grid was of this vegetation type. Reithrodontomys is a common associate of Sigmodon in such habitats. J o u le \& C a m er o $n(1974,1975)$ have found these two rodents to be co-dominants near Houston, Texas, where microtines are absent. The highly significant preference $(73 \%)$ of winter-caught cotton rats for Fitch traps suggests that trap-associated benefits strongly override punishment in the less productive environment.

The microtine rodents show preferences for Fitch traps in the winter months but not in the summer. This switch to random choice may relate to the changing age composition of the population or it may 
coincide with the apparent alteration in daily activity patterns. Both microtines appear to be strongly nocturnal in the warmer months. The strongest preference of voles for Fitch traps is in April and November, the months of probable transition. Because April and November are months of major turnover in age composition in Kansas vole populations ( $\mathrm{G}$ a in e s \& $\mathrm{R}$ o s e, in press), as well as periods of most intense energy demands of reproduction ( $\mathrm{R}$ os e, 1974), we postulate these to be principal factors favoring Fitch traps.

One of the sources of differential trap response within a species may be related to the nesting material, prairie hay in the Fitch traps and non-absorbent cotton in Sherman traps. It would appear that harvest mice find the prairie hay in the Fitch traps to fulfill many of their requirements; perhaps the size of the nest chamber is most favorable for the construction of communal nests in the wintertime or shredded native grasses form a better insulative cover than cotton for these small rodents. Of the other common small mammals, only $P$. maniculatus regularly and actively works the cotton nesting material by shredding it into a globe-shaped nest. Cotton rats and both microtines merely crawl into or on top of the cotton. By contrast, individuals of all species seem to work their way into the middle of the loosely matted ball of prairie hay in the \#10 can nest box of the Fitch trap. Thus even young individuals inexperienced in the mechanics of nest-building are able to conserve heat by simply climbing up into the ball of grass; older individuals tend to shred grasses into finer, more insulative fragments, and fashion this into a nest, usually in the center of the ball of hay. Such behavior seems to be limited to the winter months, for at other seasons the individuals seem to find the most comfortable area of confinement, which may be variously in the hardware cloth trap, on top of the hay next to the top of the can, or under the hay with belly close to the cool ground. In both studies hay and cotton were supplied or replenished only during the cooler months of the year.

Furthermore, differences in winter nesting habits are likely to be important in the seasonal preference of Fitch traps. M. ochrogaster, although it builds summer nests of balls of shredded grass above ground. in autumn digs shallow tunnels leading to underground winter nests. The winter ecology of the hispid cotton rat is poorly known. B a a r et al. (1975) report what appears to be the only account of cotton rats being underground during the wintertime. They reported unearthing three cotton rats from two nests near Hays, Kansas, one an abandoned woodchuck or badger den, the other a network of tunnels probably dug 
by prairie voles. They point out that cotton rats are poorly adapted to severe winters, and using underground tunnels would be one obvious successful adaptive strategy by those individuals to survive the winter. Little is known of the population dynamics of cotton rat populations during the winter months at latitudes comparable to Lawrence but the great weight loss by individuals that survive the winter and the high frequency of docked tails (probably from frostbite) attest to the high degree of stress placed on individuals by the winter season.

In terms of portability, there is little question that the collapsible aluminum Sherman trap is superior. By comparison, the Fitch trap weighs about $0.5 \mathrm{Kg}$ and is very bulky. However, for systematic removal or demographic studies such as ours, the Fitch traps were carried to the field only once, then left permanently in place. Fitch traps require no cleaning to remain functional, for the treadle is pendent and cannot be fouled by feces or bait. (The floor of the nest box in the Fitch trap is removable and can quickly be cleaned off in the field as the bait is added.) Furthermore, Fitch traps may benefit from having the smells associated with the species or individuals frequenting the traps (B o o ns tra, pers. comm.). Boonstra reports that soiled Longworth traps capture significantly greater numbers of Microtus townsendii compared to clean traps, suggesting that the replacement of dirty traps by clean ones prior to active trapping may be counter-productive at least in some species.

Compared to Sherman traps, Fitch traps are far more sensitive and able to capture smaller species and individuals. This factor undoubtedly contributes to the preference of harvest mice for Fitch traps in all seasons on the demographic grid, for adult harvest mice weigh about $10 \mathrm{~g}$. Similarly, newly recruited voles, about 10 days old and weighing $9-11 \mathrm{~g}$, are routinely caught only in Fitch traps. Sherman traps can be carefully adjusted so that they can catch even 4 g Cryptotis parva but the bait and feces often reduce this ability. The sensitivity of individual Sherman traps is further reduced during the winter when cotton is supplied as nesting material. As might be expected of sensitive traps, Fitch traps can be set off by pelting rain, large grasshoppers, or even land snails. However, the treadle can be adjusted to make the traps less prone to being set off by these agents.

Each live trap has its limitations with respect to predators. We have had Sherman traps removed from grids and torn open by coyotes, raccoons and possibly by feral cats. Predators can tip over Fitch traps and then extract the mouse from the nesting material or try to catch it as it flees. Predation of Fitch traps can be severe, but the traps are 
undamaged. If such predators are resident and persistent, they must be trapped and removed.

Mammals can escape from both traps, though not in the same way. In some instances a vole can slide the floor of the Fitch trap to one side and dig an opening large enough for escape. Placing a small sheet of roofing material underneath the nest box will eliminate this nuisance. Blarina has been observed to lift the galvanized door with its conical, muscular nose and to escape by turning on its back and sslithering A metal clip applied to the front of the trap will eliminate this problem. Escape from Sherman traps is mainly by Peromyscus and harvest mice, who are able to eat a hole in the aluminum door large enough to slide through. Any of these species can gnaw through the lightweight aluminium door in a single night. At Kansas we have replaced literally hundreds of aluminum doors, a task requiring dozens of hours and some expense. We would recommend buying aluminum Sherman traps with galvanized metal doors; they can be ordered this way. Fitch traps are not harmed by rodent teeth. Larger small mammals, such as Sigmodon and eastern chipmunks (Eutamias striatus), and even half-grown brown rats (Rattus norvegicus) and eastern woodrats (Neotoma floridana) are contained by Fitch and Sherman traps alike.

In summary, we have presented evidence of the superiority of Fitch traps in the ability to capture and hold in good condition several species of small mammal. The response of other species to Fitch traps is likely to be different and cannot be predicted $a$ priori. However, the analysis of seasonal effects may serve as a predictive basis for the response of any particular species. Although bulky, we believe Fitch traps to be very useful in long-term field studies, mainly because they are quickly and easily set, virtually maintenance free, not fouled by bait or feces, able to be cleaned in the field, use low cost, readily available nesting material, and have a long field life. Henry S. Fitch of the University of Kansas Natural History Reservation, the designer of the swinging treadle, drop-door trap, has intermittently used traps left continuously exposed to weather for 25 years.

Acknowledgements: We gratefully acknowledge useful comments of an earlier version of this paper given by Michael H. Smith and Rudy Boonstra, The University of Kansas General Research Fund for grants No. 3822-5038 (to M.S. Gaines) for Rose and No. 3349-5038 for Slade and Honacki, the Kansas Biological Survey, and the University of Kansas Endowment Association for providing field facilities,

\section{REFERENCES}

1. B a ar S. L., Fleharty E. D. \& Altman M. F., 1975: Utilization of deep burrows by cotton rats in west-central Kansas. SWest Nat., 19: 440-444. 
2. B a lph D. F., 1968: Behavioral responses of unconfined Uinta ground squirrels to trapping. J. Wildl. Manage, 32: 778-794.

3. Cockrum E. L., 1948: The distribution of the hispid cotton rat in Kansas. Trans. Kans. Acad. Sci., 51: 306-312.

4. Fit c h H. S., 1950: A new style live trap for small mammals. J. Mammal., 31: $364-365$.

5. Ge noways H. H. \& Schlitter D. A., 1966: Northward disperal of the hispid cotton rat in Nebraska and Missouri. Trans. Kans. Acad. Sci., 69: $356-357$.

6. Goertz J. W., 1964: The influence of habitat quality upon density of cotton rat populations. Ecol. Monogr., 34: 359-381.

7. Joule J. \& Cameron G. N., 1974: Field estimation of demographic parameters: influence of Sigmodon hispidus population structure. J. Mammal., 55: $309-318$.

8. Joule J. \& Cameron G. N., 1975: Species removal studies. I. Disperal strategies of sympatric Sigmodon hispidus and Reithrodontomys fulvescens populations. J. Mammal., 56: 378-396.

9. R o se R. K., 1973: A small mammal live trap. Trans. Kans. Acad. Sci., 76: $14-17$.

10. Ros e R. K., 1974: Reproductive, genetic and behavioral changes in populations of the prairie vole, Microtus ochrogaster, in eastern Kansas. Ph. D. Thesis, Dept. Systematics and Ecology, University of Kansas, Lawrence, Kansas USA.

11. Wi en er J. G. \& Smith M. H., 1972: Relative efficiences of four small mammal traps. J. Mammal., 53: 868-873.

Accepted, November 2, 1976.

Robert K. ROSE, Norman A. SLADE i James H. HONACKI

PREFERENCJA ŻYWOEOWEK PRZEZ SSAKI ZAMIESZKUJĄCE MURAWY

\section{Streszczenie}

Dwoma niezależnymi metodami, wyławianiem oraz znakowaniem i wypuszczaniem, porównano ze sobą dwa rodzaje pułapek żywołownych: typu Sherman i typu Fitch (Tabela 1). Porównano wydajność lowienia i możliwość otrzymywania tą drogą ssaków w dobrej kondycji, we wszystkich sezonach i w różnych warunkach pogodowych. W każdym punkcie ustawiano po jednej z każdego typu pułapek.

Stwierdzono, że Microtinae wykazują niską a Cricetinae wysoką preferencję pułapek typu Fitch. Najwyższą preferencję w stosunku do tych pułapek cechują się Reithrodontomys, we wszystkich sezonach roku (Tabela 2). Wybór określonej pułapki może zapewne zależeć od uprzedniego doświladczenia zwierząt, różnic w materiale gniazdowym (siano lub wata), lub też różnych warunków panujących wewnątrz pułapki. Żywołówki typu Sherman mają tę zaletę, że są lekkie i poręczne, lecz powodują dużą śmiertelność. Pułapki typu Sherman, choć większe i cięższe są, zdaniem autorów, znacznie lepsze, gdyż odznaczają się lepszą łownością i wyższa jest też przeżywalność ssaków łowiących się w ten typ żywołówki. 